\title{
AIR-DRYING EFFECT ON SOIL REACTION AND PHOSPHORUS EXTRACTABILITY FROM UPLAND-LOWLAND TROPICAL SOILS AS RELATED TO THEIR COLLOIDAL STABILITY
}

\author{
OBALUM, S. E. ${ }^{*}$ - CHIBUIKE, G. U. \\ Department of Soil Science, Faculty of Agriculture, University of Nigeria \\ Nsukka 410001, Nigeria \\ *Corresponding author \\ e-mail:sunday.obalum@unn.edu.ng,ijewelle@yahoo.com \\ (phone: +234803-968-8755) \\ (Received $6^{\text {th }}$ Jul 2016; accepted $6^{\text {th }}$ Oct 2016)
}

\begin{abstract}
Although air-drying is a universally accepted practice for preserving soils before analyses, it can irreversibly affect certain soil processes and, hence, results of soil analyses. Reports about such effects on extractable/available phosphorus $\left(\mathrm{P}_{\mathrm{av}}\right)$ are conflicting and are scanty for low- $\mathrm{P}_{\mathrm{av}}$ tropical soils. Moreover, little is known about its relative effects for well and poorly drained soils or about any underlying role of soil colloidal stability. In this study, soil samples from well-drained uplands and adjoining poorly drained lowlands in four locations in southeastern Nigeria were analysed field-moist and air-dried for $\mathrm{pH}$ and $\mathrm{P}_{\mathrm{av}}$. The soils are mostly medium-textured. A trend existed of drying-induced decreases in soil $\mathrm{pH}$ for both uplands (4.8-5.8) and lowlands (4.6-5.6); whereas this effect was consistently non-significant in the former (unless tested for irrespective of location, 5.35 vs 5.53), it was location-specific in the latter. Airdrying tended to increase and decrease $\mathrm{P}_{\mathrm{av}}$ in upland soils $\left(0.62-12.75 \mathrm{mg} \mathrm{kg}^{-1}\right)$ and lowland soils $(0.93-$ $20.52 \mathrm{mg} \mathrm{kg}^{-1}$ ), respectively, with a reverse effect in one lowland with values exceeding $15 \mathrm{mg} \mathrm{kg}^{-1}$. However, these effects were non-significant except in one upland soil with evidence of appreciable organic matter. Correlations between soil $\mathrm{pH}$ and $\mathrm{P}_{\mathrm{av}}$ were positive and non-significant, but strongest for field-moist lowland soils. Soil colloidal stability indices of water-dispersible clay and clay flocculation index proved useful in understanding the results for soil $\mathrm{pH}$ and $\mathrm{P}_{\mathrm{av}}$, respectively, with the effect of the former being more distinct than that of the latter. Air-drying is still recommended only for upland soils while we explore fully the interrelationships among drying-induced differences and colloidal stability for soils of contrasting drainage status.
\end{abstract}

Keywords: available phosphorus, clay flocculation index, field-moist soil samples, microaggregate stability, poorly drained soils

\section{Introduction}

Air-drying soil samples before analyses is a common practice in most laboratories. This is because air-drying allows soil samples to be stored for analyses even after a long time, since dried soil samples are perceived to undergo minimal changes caused by microbial and chemical reactions compared to field-moist samples (Erich and Hoskins, 2011). It equally increases the ease of handling of soil samples during analyses. However, air-drying soils before analysis often increases the concentration of solutes in soil solution which may later be precipitated or lead to an increased sorption on soil surfaces (Erich and Hoskins, 2011), and this may influence the results of soil analyses for easily sorbed soil chemical constituents. When solutes precipitate in air-dried soils, their complete solubility after rewetting such soils is unlikely. It has been shown repeatedly that drying increases surface acidity, and that this phenomenon can affect the solubility and availability of many nutrients including phosphorus (Bartlett and James, 1980; Haynes and Swift, 1985; Erich and Hoskins, 2011). 
Probably because of the agronomic and environmental importance of phosphorus, its extractability from soil as affected by air-drying has been studied extensively, although with conflicting reports. Studies reporting increases in available phosphorus with airdrying (Gilliam and Richter, 1988; Srivastava, 1997; Yongsong et al., 1998; Schaerer et al., 2005; Erich and Hoskins, 2011; Achat et al., 2012; Xiao et al., 2012) seem to outnumber those that found no such effect (Ekpete, 1976; Peltovuori and Soinne, 2005; Soinne et al., 2010; Xu et al., 2011), which in turn seem to outnumber those reporting decreases in extractable phosphorus with air-drying (Haynes and Swift, 1985). With the exception of the pilot studies by Ekpete (1976), Srivastava (1997) and Yongsong et al. (1998) which were carried out on tropical soils and that by Gilliam and Richter (1988) in a sub-tropical environment, the rest of the studies just cited were carried out on soils from temperate locations.

Considering the comparatively low concentration of available phosphorus in tropical soils particularly those of West Africa (Enwezor and Moore, 1966; Owusu-Bennoah et al., 1995), the issue of differing values of available phosphorus between air-dried and field-moist soils should be of greater concern to researchers in the tropics. On the other hand, the relationships between soil $\mathrm{pH}$ and phosphorus availability have been extensively studied on tropical soils (Mokwunye, 1975; Eze and Loganathan, 1990; Sato and Comerford, 2005; among others), and some of such studies show that the low availability of phosphorus in tropical soils is often exacerbated by the acidic nature of the soils (e.g., Sato and Comerford, 2005). Yet, as with phosphorus availability, there is paucity of data about the influence of air-drying soil samples before analysis on soil reaction in tropical soils.

Notably, research has implicated appreciable concentration of organic matter in soils as being responsible for the differences in soil available phosphorus induced by airdrying (Schaerer et al., 2003; Xiao et al., 2012). The majority of tropical soils show low values of organic matter concentration, often not exceeding $10 \mathrm{~g} \mathrm{~kg}^{-1}$ of soil. In tropical watersheds, however, organic matter and plant nutrients are usually lower in upland soils compared to adjoining lowland soils due to geological fertilization (Obalum et al., 2012a), as well as to poor drainage status of the latter. The quest for clear-cut information on the effect of drying on phosphorus availability in tropical soils should therefore not be limited to well-drained upland soils but also extended to adjoining poorly drained lowland soils. This approach is rare in the literature (Gilliam and Richter, 1988), but can have additional benefits. In lowland sawah rice systems of West Africa where phosphorus availability is suggested to promote rice yields (Obalum et al., 2014), for instance, such information also for lowland soils can help to develop strategies for managing phosphorus in sawah soils.

Furthermore, the present study considered a possible interdependence among soil $\mathrm{pH}$, available phosphorus and structural stability at the colloidal level. Soil $\mathrm{pH}$ influences phosphorus availability (Sato and Comerford, 2005) as well as colloidal stability of the soil (Igwe and Udegbunam, 2008). Among the soil processes known to be important in colloidal stability is alternate wetting and drying (de Oliveira et al., 2005). Since the practice of drying initially wet soil samples and rewetting them before analyses simulates a wetting-drying cycle, at two extremes though, the response of soil $\mathrm{pH}$ and/or phosphorus to air-drying may be a reflection of change in soil colloidal stability induced by such drying. This hypothesis is yet to receive the attention of any research, going by our review of the literature. Because of their topographical and hydrological differences that promote geological fertilization, uplands and lowlands 
often differ not only in organic matter and drainage status but also in texture. Many other related soil properties, including colloidal stability, differ between them too. Again, this makes the concurrent study of uplands and lowlands in this study imperative.

In this study, four upland soils and adjoining lowland soils with clearly contrasting drainage status and occurring in four locations of southeastern Nigeria were sampled and analysed for $\mathrm{pH}$ and available phosphorus with and without air-drying. Some easily measurable indices of soil colloidal stability were equally derived. The objectives of the study were to assess: (i) the effect of air-drying on soil test results for $\mathrm{pH}$ and available phosphorus in well and poorly drained soils, (ii) the nature of the relationships between $\mathrm{pH}$ and phosphorus availability in air-dried and field-moist soils, and (ii) the role of soil colloidal stability in any effect of air-drying on these two soil properties.

\section{Materials and Methods}

\section{Study sites and soil sampling}

The study was conducted using soils from four locations in southeastern Nigeria, including Agbobu, Akaeze, Nando and Omasi (Figure 1). Some climatic and ecological features of these locations are briefly described in Table 1.

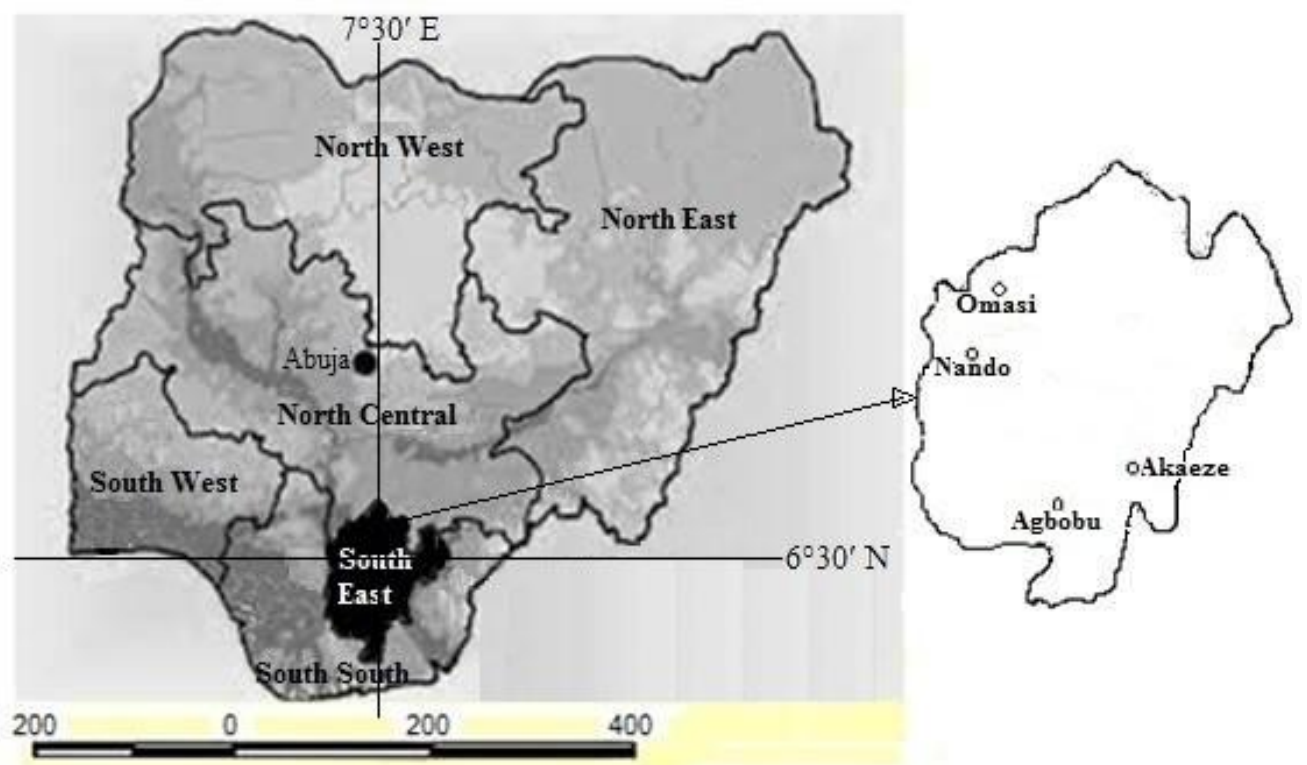

Figure 1. Map of Nigeria showing southeastern Nigeria and the study locations

Soils were sampled from an upland-lowland setting in all the four locations during the rainy season of tropical Africa, when the difference in drainage status of upland soils and adjoining lowland soils is usually most evident. At each location, three samples were collected from random spots along a short transect of about $20 \mathrm{~m}$ in each of the two topographic positions, giving 12 samples of upland soils and 12 samples of lowland soils. In all four locations, transects in the uplands were somewhat parallel to those in the lowlands, and were approximately $50 \mathrm{~m}$ apart. Soil samples were collected from 0-20 cm depth using an auger, packaged in black polythene bags and conveyed to the laboratory. 
Table 1. Brief description of study sites

\begin{tabular}{|c|c|c|c|}
\hline \multirow[b]{2}{*}{ Location } & \multicolumn{2}{|c|}{ Climate (mean annual) } & \multirow[b]{2}{*}{ Vegetation zone } \\
\hline & $\begin{array}{c}\text { Rainfall }^{\dagger} \\
(\mathrm{mm})\end{array}$ & $\begin{array}{c}\text { Temperature } \\
\left({ }^{\circ} \mathrm{C}\right)\end{array}$ & \\
\hline Agbobu & $\begin{array}{c}2250 \\
(\sim 4 \text { months })\end{array}$ & $27-28$ & Humid rainforest \\
\hline Akaeze & $\begin{array}{c}1350 \\
(\sim 5 \text { months })\end{array}$ & 29 & Derived savannah \\
\hline Nando & $\begin{array}{c}2300 \\
(\sim 4 \text { months })\end{array}$ & 28 & Humid rainforest \\
\hline Omasi & $\begin{array}{c}2000 \\
(\sim 4 \text { months })\end{array}$ & 29 & $\begin{array}{l}\text { Forest-Savannah } \\
\text { Transition }\end{array}$ \\
\hline
\end{tabular}

${ }^{\dagger}$ Dry season length is enclosed in parenthesis.

The soil samples were each partitioned into two equal parts by mass. One part was weighed and its field-moist mass, $\mathrm{M}_{\mathrm{fm}}$, recorded before being air-dried for $48 \mathrm{~h}$ under laboratory conditions after which its air-dried mass, $\mathbf{M}_{\mathrm{ad}}$, was also recorded. The other part was not air-dried but preserved in its field-moist condition. Both air-dried and fieldmoist soil samples were passed through a $2-\mathrm{mm}$ sieve before laboratory analyses.

\section{Soil laboratory analyses}

Particle size distribution was determined on air-dried samples by mechanical analysis using the Hydrometer method described by Gee and Bauder (1986), and this was done twice per sample; one with and the other without $0.1 \mathrm{~N} \mathrm{NaOH}$ as dispersing agent, to enable the derivation of some soil colloidal stability indices. Soil $\mathrm{pH}$ was determined in suspensions of soil in both deionized water and $\mathrm{KCl}$ in a soil-liquid ratio of 1.0:2.5 (Mclean, 1982). Available phosphorus was extracted with Bray II, as this reagent is very effective for extracting phosphorus from acid soils of southeastern Nigeria (Enwezor, 1977). The determination was done using the method described by Olsen and Sommers (1982). For soil $\mathrm{pH}$ and available phosphorus, the amounts of air-dried soil samples used in the analyses were as recommended by the standard methods cited $(10 \mathrm{~g}$ and $5 \mathrm{~g}$, respectively), while the amounts of field-moist samples used were the equivalent masses, obtained thus:

$$
E M_{f m}=\frac{R M_{a d} \times M_{f m}}{M_{a d}}
$$

where $\mathrm{EM}_{\mathrm{fm}}$ is the equivalent mass of field-moist soil sample used for analysis; $\mathrm{RM}_{\mathrm{ad}}$ is the recommended mass of air-dried sample for use in analysis; and $\mathrm{M}_{\mathrm{fm}}$ and $\mathrm{M}_{\mathrm{ad}}$ are the recorded masses of the sample in its field-moist and air-dried conditions, respectively before analyses.

\section{Soil colloidal stability indices}

The following easily measurable colloidal stability indices of the soils were derived after mechanical analysis for particle size distribution (Igwe and Obalum, 2013): 
(i) Water-dispersible silt $(\mathrm{WDSi})=$ Silt content of the soil (\%) obtained after mechanical analysis without dispersing agent. The lower the value of WDSi, the greater the colloidal stability of the soil.

(ii) Water-dispersible clay (WDC) = Clay content of the soil (\%) obtained after mechanical analysis without dispersing agent. The lower the value of WDC, the greater the colloidal stability of the soil.

(iii) Clay flocculation index $(\mathrm{CFI})=($ Total clay $-\mathrm{WDC}) /$ Total clay. The higher the value of CFI, the greater the colloidal stability of the soil.

\section{Statistical analysis}

Preliminary comparison of the uplands and the lowlands using t-test revealed that they differed in soil $\mathrm{pH}\left(5.44\right.$ and 4.94 , respectively; $\left.t_{\text {cal }}=2.82^{*}\right)$ but not in available phosphorus (5.91 and $8.32 \mathrm{mg} \mathrm{kg}{ }^{-1}$, respectively; $t_{\text {cal }}=0.80^{\text {ns }}$ ). These differences observed, though in one out of the two soil parameters considered, informed the decision to analyse the data separately for the two topographic positions. One-way analysis of variance (ANOVA) was used to test for differences in $\mathrm{pH}$ and available phosphorus between air-dried and field-moist soils from each of the four locations. Treatment means were deemed different at $p \leq 0.05$. Such statistically significant differences between means were detected using Tukey's family error rate. Furthermore, we regarded locations as replications and subjected treatment means for soil $\mathrm{pH}$ and available phosphorus from all locations to t-test in order to compare the grand means for air-dried and field-moist soils. Again this was done separately for upland and lowland soils. Correlation and regression analyses were used to examine the relationships between soil $\mathrm{pH}$ and phosphorus extractability from the air-dried and field-moist soils. Regression analysis was also used to examine the nature of the relationships between treatment effect and selected indices of colloidal stability of the soils, on one hand and between mean values for air-dried and field-moist soils, on the other. All analyses were carried out using the two software, Minitab 17 and Microsoft excel sheet.

\section{Results and Discussion}

Both upland and lowland soils from the study locations are generally of medium texture except for Nando where the soil is fine-textured, especially at the upland region (Table 2). Instead of coarser soil texture due to natural flow of sediments, the uplands show similar soil texture as the lowlands in two of the locations (Akaeze and Omasi), and even finer texture than the lowlands in the other two, Agbobu and Nando, both of where the sampled sites are on a gently rolling terrain. Owusu-Bennoah et al. (2000) reported similar scenario on a gentle topography in Ghana and attributed it to mixing of the lowland part of the topography with alluvial sediments. In our opinion, the present results suggest that clay eluviation/illuviation is pronounced in the concerned soils, such that upland-lowland surface erosion exposes the illuvial, finer-textured layer in the uplands while leaving the adjoining lowlands coarser.

The upland soils showed generally lower values of water-dispersible clay (WDC) and higher values of clay flocculation index (CFI) compared to their lowland counterparts, implying greater colloidal stability of the uplands than the lowlands. The well-drained condition of the uplands as against the seasonally flooded condition of the lowlands would explain this observation (Obalum et al., 2014). The data in Table 2 also show that soils from Nando had higher contents of water-dispersible silt (WDSi) than 
total silt and were more stable than soils from the other locations. That the silt content without dispersion is higher than that after 'complete' dispersion for these clayey soils is not an aberration. This observation rather suggests that, in the soil-water suspension without a dispersing agent, some flocculated clay particles could not be dispersed and so posed as silt particles, and this resulted in the high CFI and hence high colloidal stability of the soils. The next to Nando in terms of fineness of soil texture is Akaeze but it showed the lowest CFI and hence the lowest stability, an indication that clay flocculation and colloidal stability are not attributes of fine soil texture, but of other soil factors (Mbagwu and Schwertmann, 2006; Igwe and Obalum, 2013).

Table 3 shows that, for both uplands and lowlands of the four locations, soil $\mathrm{pH}$ tended to be lower in air-dried samples compared to the field-moist samples, and that the only cases of significant differences were in the lowland soils - Akaeze for $\mathrm{pH}$ in both water and $\mathrm{KCl}$, Omasi for $\mathrm{pH}$ in water and Nando for $\mathrm{pH}$ in $\mathrm{KCl}$. The decrease in $\mathrm{pH}$ of some of the soils due to air-drying and the associated increase in surface acidity has similarly been reported elsewhere (Erich and Hoskins, 2011). The chemistry of drying mineral surfaces and its acidifying effect on soil surface can be found in Dowding et al. (2005). For the upland soils, $\mathrm{pH}$ of air-dried samples only showed tendency for lower values which were not significantly different from those of fieldmoist samples, suggesting that the acidifying effect of drying on soil surface may not be pronounced in well-drained upland soils. Conversely, the significant treatment effect on soil $\mathrm{pH}$ in water for the lowland soils only at Akaeze and Omasi may be linked to the high tendency for clay dispersion in these two locations (particularly the former) compared to Agbobu and Nando, as evident in the values for WDC and CFI.

When the entire soils of the study were considered together irrespective of location, the differences in soil $\mathrm{pH}$ between the air-dried and the field-moist samples were significant for the upland soils but not for the lowland soils. The results suggest such that differences in parent material and hence soil texture are needed for the acidifying effect of drying to manifest in well-drained soils, but that such underlying influence of texture on the acidifying effect of drying can be masked in poorly drained soils. Overall, these results imply that the effect of air-drying on $\mathrm{pH}$ of well-drained soils may be unimportant at local scales but may be important at the regional scale, and vice versa for poorly drained soils.

Notably, values for the $\mathrm{pH}$ gradient $\left(\mathrm{pH}-\mathrm{H}_{2} \mathrm{O}\right.$ minus $\left.\mathrm{pH}-\mathrm{KCl}\right)$ were generally higher for the field-moist samples than for the air-dried samples of the uplands soils; the reverse was true for the lowland soils except for Omasi. The upland soils thus conformed to the normal pattern of $\mathrm{pH}$ range in soils whereby such values increase with increasing $\mathrm{pH}$ in water (Thomas, 1996). This was not the case for the lowland soils in which air-drying had greater acidifying effect, implying that their air-dried samples had higher concentration of $\mathrm{H}^{+}$than the field-moist samples. Because $\mathrm{H}_{2} \mathrm{O}$ displaces less $\mathrm{H}^{+}$ from soil colloids than $\mathrm{KCl}$, the soil solution in $\mathrm{KCl}$ probably had more displaced $\mathrm{H}^{+}$ which lowered further the value for $\mathrm{pH}-\mathrm{KCl}$ in the air-dried samples of the lowland soils, hence the observation.

For both air-dried and field-moist samples, upland soils consistently showed higher $\mathrm{pH}$ values compared to their lowland counterparts; the only exception was the fieldmoist samples of soils from Akaeze. This higher acidity level of the lowland soils is surprising, considering the relatively reduced soil condition of the lowlands, which was expected to lower soil acidity. Obalum et al. (2012b) reported similar acidity problem in some lowland sawah soils from northcentral Nigeria, in spite of the reduced condition 
of those soils. However, runoff and sediments from uplands normally accumulates in lowlands in typical upland-lowland setting (Obalum et al., 2012a), and often contain dissolved organic matter. Although the reduced condition of lowlands helps to preserve their soil organic matter, partial oxidation following intermittent periods of aerobiosis is also possible; and such a situation can increase soil acidity. Furthermore, since sandy soils are more prone to acidification (Marx et al., 1999), the generally finer texture of the upland soils compared to their lowland counterparts (which is particularly true for Agbobu and Nando soils; see Table 2) may have also contributed to the observed lower acidity of the upland soils than the lowland soils.

In the upland soils, values for soil available phosphorus were generally higher in airdried samples compared to field-moist samples, but the differences were significant only for Akaeze (Table 4). Several authors have reported increased phosphorus extractability from soil with drying (Yongsong et al., 1998; Erich and Hoskins, 2011; Achat et al., 2012; Xiao et al., 2012). The major factors contributing to this phenomenon include mineralization of soil organic matter and lysis of microbial cells (Srivastava, 1997; Yongsong et al., 1998; Xu et al., 2011; Xiao et al., 2012). This is particularly true for soils high in organic matter (Xu et al., 2011; Achat et al., 2012). Soil organic matter was not determined in the present study, but the soils are known to be typically low in organic matter (Obalum et al., 2013), hence the generally insignificant drying-induced differences in extractable phosphorus. Peltovuori and Soinne (2005) argue that the destruction of organomineral complexes by air-drying simultaneously releases phosphorus and exposes new surfaces on which phosphorus could sorb.

The significant differences for Akaeze soil could be explained by its high clay content (see Table 2) which suggests a greater potential for formation of clay-organic complexes that can protect organic matter against rapid mineralization and loss. The soil also had the highest content of WDC, which tends to increase with an increase in organic matter in upland soils (Igwe and Udegbunam, 2008). The higher extractable phosphorus in the air-dried than the field-moist samples observed only for Akaeze soil was therefore attributed to the possible relatively high concentration of organic matter which was less stable to the oxidizing condition of air-drying (Gilliam and Richter, 1988). In such high-organic matter soils, the disruption of stable aggregates after drying and sieving also facilitates the release of inorganic phosphorus tied up in Fe-Alphosphate complexes (Peltovuori and Soinne, 2005; Erich and Hoskins, 2011; Achat et al., 2012). Kaiser et al. (2015) document the influence of drying on aggregates, quantity and quality of dissolved organic matter, and soil microbiota.

Conversely, available phosphorus of the lowland soils tended to be higher in fieldmoist samples compared to air-dried samples, except for Omasi. Ekpete (1976) made similar observation in some waterlogged Nigerian soils, and so concluded that airdrying be still done when analysing such soils for phosphorus availability. It appears, therefore, that significant or non-significant decrease rather any increase in available phosphorus with air-drying should be expected in poorly drained tropical soils. The reason for the deviation of Omasi lowland soil from this trend is not clear, although it may be related to the 'high' value $\left(>15 \mathrm{mg} \mathrm{kg}^{-1}\right)$ of available phosphorus in the soil compared to the other locations. This reasoning is supported by the range of available phosphorus for Omasi lowland soil being similar to the range in other tropical soils (16.4-28.3 mg kg-1, also Olsen-P) where air-drying was also reported to increase phosphorus extractability (Yongsong et al., 1998). 
Table 2. Textural properties and colloidal stability indices of the experimental soils

\begin{tabular}{|c|c|c|c|c|c|c|c|c|}
\hline Location & $\begin{array}{l}\text { Topographic } \\
\text { position }\end{array}$ & Sand & $\begin{array}{l}\text { Silt } \\
(\%)\end{array}$ & Clay & $\begin{array}{l}\text { Textural } \\
\text { class }\end{array}$ & $\begin{array}{c}\text { WDSi } \\
(\%)\end{array}$ & $\begin{array}{c}\text { WDC } \\
(\%)\end{array}$ & CFI \\
\hline \multirow[t]{2}{*}{ Agbobu } & Upland & 51.8 & 31.4 & 16.8 & Loam & 29.4 & 4.8 & 0.71 \\
\hline & Lowland & 73.8 & 17.4 & 8.8 & Sandy loam & 11.4 & 4.8 & 0.45 \\
\hline \multirow[t]{2}{*}{ Akaeze } & Upland & 39.8 & 29.4 & 30.8 & Clay loam & 27.4 & 16.8 & 0.45 \\
\hline & Lowland & 43.8 & 23.4 & 32.8 & Clay loam & 17.4 & 24.8 & 0.24 \\
\hline \multirow[t]{2}{*}{ Nando } & Upland & 41.8 & 17.4 & 40.8 & Clay & 29.4 & 6.8 & 0.83 \\
\hline & Lowland & 45.8 & 11.4 & 42.8 & Sandy clay & 29.4 & 10.8 & 0.75 \\
\hline \multirow[t]{2}{*}{ Omasi } & Upland & 59.8 & 25.4 & 14.8 & Sandy loam & 21.4 & 6.8 & 0.54 \\
\hline & Lowland & 59.8 & 21.4 & 18.8 & Sandy loam & 21.4 & 8.8 & 0.53 \\
\hline
\end{tabular}

WDSi-water-dispersible silt; WDC-water-dispersible clay; CFI-clay flocculation index 
Table 3. Air-drying effect on $\mathrm{pH}$ of some upland and lowland soils in southeastern Nigeria

\begin{tabular}{|c|c|c|c|c|c|c|c|}
\hline \multirow[b]{2}{*}{ Location } & \multirow[b]{2}{*}{ Treatment } & \multicolumn{3}{|c|}{ Upland } & \multicolumn{3}{|c|}{ Lowland } \\
\hline & & $\mathrm{pH}-\mathrm{H}_{2} \mathrm{O}(\mathrm{I})$ & $\mathrm{pH}-\mathrm{KCl}$ (II) & $\begin{array}{c}\Delta \mathrm{pH} \\
(\mathrm{I}-\mathrm{II})\end{array}$ & $\mathrm{pH}-\mathrm{H}_{2} \mathrm{O}(\mathrm{I})$ & $\mathrm{pH}-\mathrm{KCl}$ (II) & $\begin{array}{c}\Delta \mathrm{pH} \\
(\mathrm{I}-\mathrm{II})\end{array}$ \\
\hline \multirow[t]{2}{*}{ Agbobu } & Air-dried & $5.3^{\mathrm{a}} \pm 0.12$ & $4.7^{\mathrm{a}} \pm 0.15$ & 0.6 & $4.9^{\mathrm{a}} \pm 0.10$ & $3.8^{\mathrm{a}} \pm 0.03$ & 1.1 \\
\hline & Field-moist & $5.6^{\mathrm{a}} \pm 0.12$ & $4.8^{\mathrm{a}} \pm 0.17$ & 0.8 & $4.9^{\mathrm{a}} \pm 0.12$ & $3.9^{\mathrm{a}} \pm 0.05$ & 1.0 \\
\hline \multirow[t]{2}{*}{ Akaeze } & Air-dried & $4.8^{\mathrm{a}} \pm 0.09$ & $3.8^{\mathrm{a}} \pm 0.09$ & 1.0 & $4.6^{\mathrm{b}} \pm 0.06$ & $3.6^{\mathrm{b}} \pm 0.06$ & 1.0 \\
\hline & Field-moist & $4.9^{\mathrm{a}} \pm 0.12$ & $3.8^{\mathrm{a}} \pm 0.09$ & 1.1 & $5.6^{\mathrm{a}} \pm 0.03$ & $4.7^{\mathrm{a}} \pm 0.05$ & 0.9 \\
\hline \multirow[t]{2}{*}{ Nando } & Air-dried & $5.6^{\mathrm{a}} \pm 0.03$ & $4.7^{\mathrm{a}} \pm 0.03$ & 0.9 & $4.7^{\mathrm{a}} \pm 0.03$ & $3.9^{b} \pm 0.06$ & 0.8 \\
\hline & Field-moist & $5.8^{\mathrm{a}} \pm 0.16$ & $4.9^{\mathrm{a}} \pm 0.07$ & 0.9 & $4.9^{\mathrm{a}} \pm 0.09$ & $4.2^{\mathrm{a}} \pm 0.09$ & 0.7 \\
\hline \multirow[t]{2}{*}{ Omasi } & Air-dried & $5.7^{\mathrm{a}} \pm 0.09$ & $4.9^{\mathrm{a}} \pm 0.17$ & 0.8 & $4.8^{b} \pm 0.06$ & $3.8^{\mathrm{a}} \pm 0.03$ & 1.0 \\
\hline & Field-moist & $5.8^{\mathrm{a}} \pm 0.15$ & $4.9^{\mathrm{a}} \pm 0.17$ & 0.9 & $5.1^{\mathrm{a}} \pm 0.06$ & $3.9^{\mathrm{a}} \pm 0.03$ & 1.2 \\
\hline \multirow[t]{3}{*}{ All locations ${ }^{\dagger}$} & Air-dried & $5.35^{\mathrm{b}} \pm 0.20$ & $4.52^{\mathrm{a}} \pm 0.25$ & 0.83 & $4.75^{\mathrm{a}} \pm 0.06$ & $3.78^{a} \pm 0.06$ & 0.97 \\
\hline & Field-moist & $5.53^{\mathrm{a}} \pm 0.21$ & $4.60^{\mathrm{a}} \pm 0.27$ & 0.93 & $5.13^{\mathrm{a}} \pm 0.17$ & $4.18^{\mathrm{a}} \pm 0.19$ & 0.95 \\
\hline & & $\left(t_{\mathrm{cal}}=3.66 ; p=0.04\right)$ & $\left(t_{\text {cal }}=1.57 ; p=0.22\right)$ & & $\left(t_{\mathrm{cal}}=1.72 ; p=0.18\right)$ & $\left(t_{\mathrm{cal}}=1.68 ; p=0.19\right)$ & \\
\hline
\end{tabular}

Values are means \pm standard error of the mean. For each location, means for air-dried and field-moist samples that do not share a letter are significantly $(p \leq 0.05)$ different. ${ }^{\dagger}$ Comparison based on the mean values from the four locations by t-test. 
Overall, the results of the t-test analysis indicated no significant differences in the values for available phosphorus between air-dried and field-moist samples for both the upland soils and the lowland soils (Table 4). These results imply that air-drying lowers the extractability of phosphorus from the soils (irrespective of drainage status), but such decreases are often not appreciable and are not a problem at the regional scale. Our data support Kaiser et al. (2015) who concluded in their review that air-drying effect is location-specific. Notably, phosphorus status was generally lower in upland soils compared to lowland soils across the locations. This would be explained by the fact that, in wet soils, redox reaction releases phosphorus while the dissolution of iron (III) oxyhydroxides further releases immobilized phosphorus (Obalum et al., 2012b; Rabeharisoa et al., 2012).

Table 4. Air-drying effect on available phosphorus $\left(\mathrm{mg} \mathrm{kg}^{-1}\right)$ of some upland and lowland soils in southeastern Nigeria

\begin{tabular}{|c|c|c|c|}
\hline Location & Treatment & Upland & Lowland \\
\hline \multirow[t]{2}{*}{ Agbobu } & Air-dried & $4.04^{\mathrm{a}} \pm 1.24$ & $4.35^{\mathrm{a}} \pm 1.12$ \\
\hline & Field-moist & $4.04^{\mathrm{a}} \pm 1.73$ & $4.35^{\mathrm{a}} \pm 1.55$ \\
\hline \multirow[t]{2}{*}{ Akaeze } & Air-dried & $7.46^{\mathrm{a}} \pm 0.54$ & $7.77^{\mathrm{a}} \pm 0.62$ \\
\hline & Field-moist & $4.97^{b} \pm 0.31$ & $10.88^{\mathrm{a}} \pm 1.73$ \\
\hline \multirow[t]{2}{*}{ Nando } & Air-dried & $0.93^{\mathrm{a}} \pm 0.54$ & $0.93^{\mathrm{a}} \pm 0.54$ \\
\hline & Field-moist & $0.62^{\mathrm{a}} \pm 0.62$ & $1.24^{\mathrm{a}} \pm 0.31$ \\
\hline \multirow[t]{2}{*}{ Omasi } & Air-dried & $12.75^{\mathrm{a}} \pm 0.82$ & $20.52^{\mathrm{a}} \pm 3.53$ \\
\hline & Field-moist & $12.43^{\mathrm{a}} \pm 1.35$ & $16.48^{\mathrm{a}} \pm 5.00$ \\
\hline \multirow[t]{3}{*}{ All locations ${ }^{\dagger}$} & Air-dried & $6.30^{\mathrm{a}} \pm 2.53$ & $8.39^{\mathrm{a}} \pm 4.28$ \\
\hline & Field-moist & $5.51^{\mathrm{a}} \pm 2.49$ & $8.24^{\mathrm{a}} \pm 3.40$ \\
\hline & & $\left(t_{\mathrm{cal}}=-1.35 ; p=0.27\right)$ & $\left(t_{\mathrm{cal}}=-1.05 ; p=0.92\right)$ \\
\hline
\end{tabular}

Values are means \pm standard error of the mean. For each location, means for air-dried and field-moist samples that do not share a letter are significantly $(p \leq 0.05)$ different.

${ }^{\dagger}$ Comparison based on the mean values from the four locations by t-test.

The correlation analyses between soil $\mathrm{pH}$ and extractable phosphorus done separately for the air-dried and the field-moist soils ( $n=12$ in each case) indicated non-significant positive coefficients, $r ; 0.057$ and 0.139 , respectively for the upland soils and 0.079 and 0.206 , respectively for the lowland soils. These poor relationships between $\mathrm{pH}$ and phosphorus availability in these soils are attributed to the low range of soil $\mathrm{pH}$, a situation which gives no room for an appreciable reduction in phosphorus sorption by Fe-Al-phosphate complexes. Loganathan et al. (1987) reported similar observation in some soils from southern Nigeria. It also seems that soil $\mathrm{pH}$ has pronounced influence on phosphorus availability in weathered tropical soils only under conditions of high phosphorus levels attained by addition of phosphorus solution to soil (Eze and Loganathan, 1990), or when soils are treated with liming materials to enhance normal distribution of their $\mathrm{pH}$ values (Sato and Comerford, 2005).

Though non-significant, the above correlation coefficients suggest a tendency for weaker positive $\mathrm{pH}$-phosphorus relationships in air-dried than field-moist samples, on one hand and in well drained upland soils than in poorly drained lowland soils of the tropics, on the other. The results provide a clue for defining priorities in any $\mathrm{pH}$-based management of low 
phosphorus availability in upland and lowland soils of tropical watersheds, particularly lowland sawah systems of rice production in West Africa where phosphorus availability has been suggested to increase rice yields (Obalum et al., 2014).

Since the relationship between soil $\mathrm{pH}$ and available phosphorus was weak, the regression was not shown; instead, emphasis was shifted to the relationships between $\mathrm{pH}$ in air-dried and field-moist soils and between available phosphorus in air-dried and field-moist soils which were much stronger. The best regression between $\mathrm{pH}$ values in air-dried soils and those in field-moist soils was of the polynomial form of the second order; the corresponding regression for available phosphorus was of the power form (Figure 2). It can be deduced from these relationships that air-drying of soil samples before analyses has a less distinct effect on soil $\mathrm{pH}$ than on extractability of phosphorus from the soil.

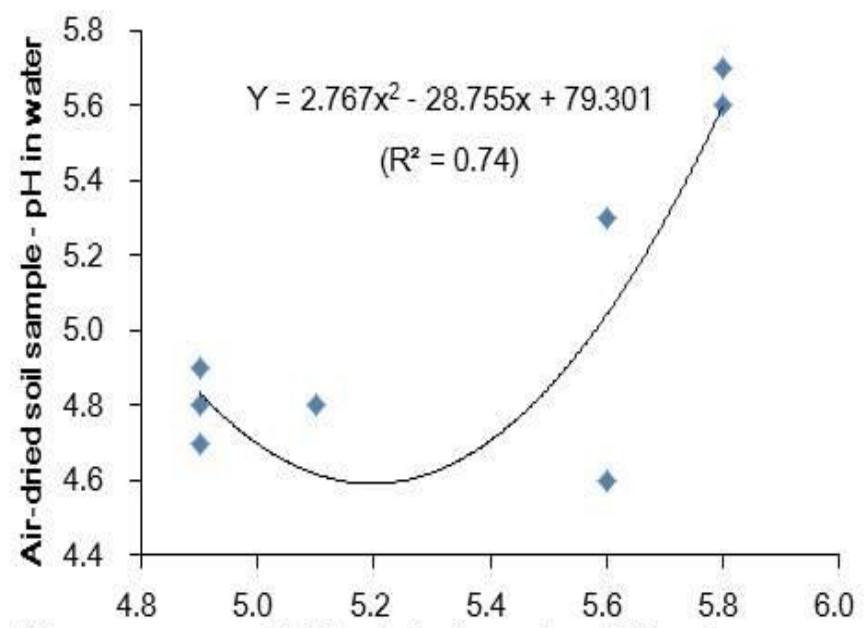

(a) Field-moist soil sample- $\mathrm{pH}$ in water

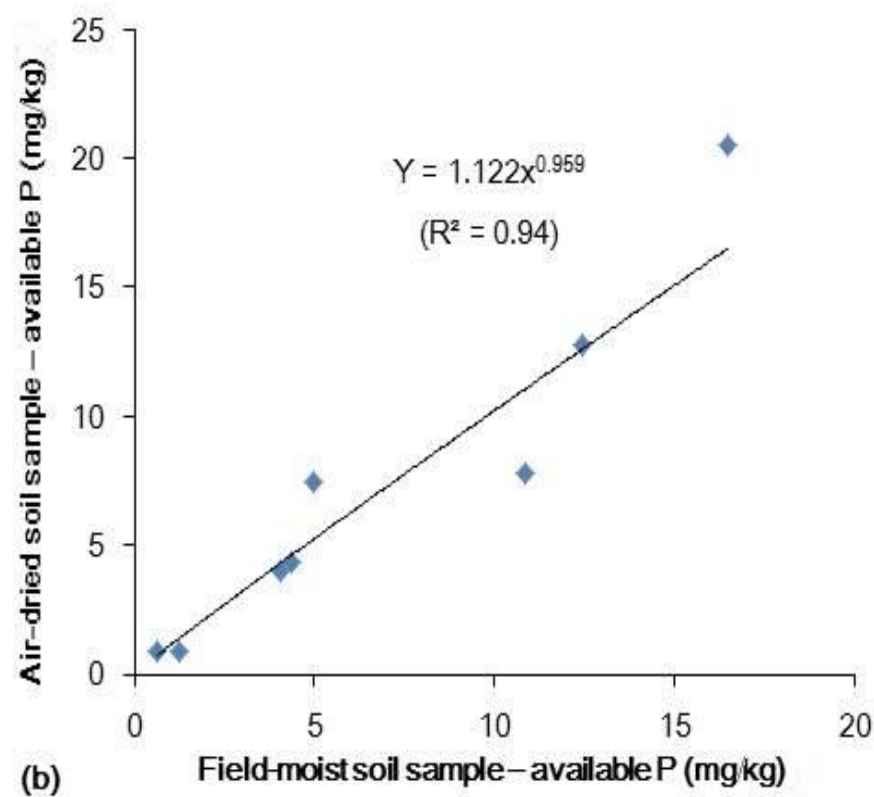

Figure 2. Relationships between mean values of soil $\mathrm{pH}-\mathrm{H}_{2} \mathrm{O}$ in air-dried samples and in fieldmoist samples of the (a) upland soils and (b) lowland soils 
The effect of air-drying on soil $\mathrm{pH}$ showed a very strong dependence on WDC contents of the soils, irrespective of drainage status, as evident in the regression of squared differences (between means for air-dried and field-moist samples) in $\mathrm{pH}$ on WDC contents of the soils (Figure 3). Thus, drying-induced differences in soil $\mathrm{pH}$ can be predicted very well from WDC content of the soil alone. The regression was of the polynomial form, implying that such differences are related to soil content of WDC in curvilinear manner. In other words, the drying-induced difference in soil $\mathrm{pH}$ increases polynomially with an increase in WDC content of the soil.

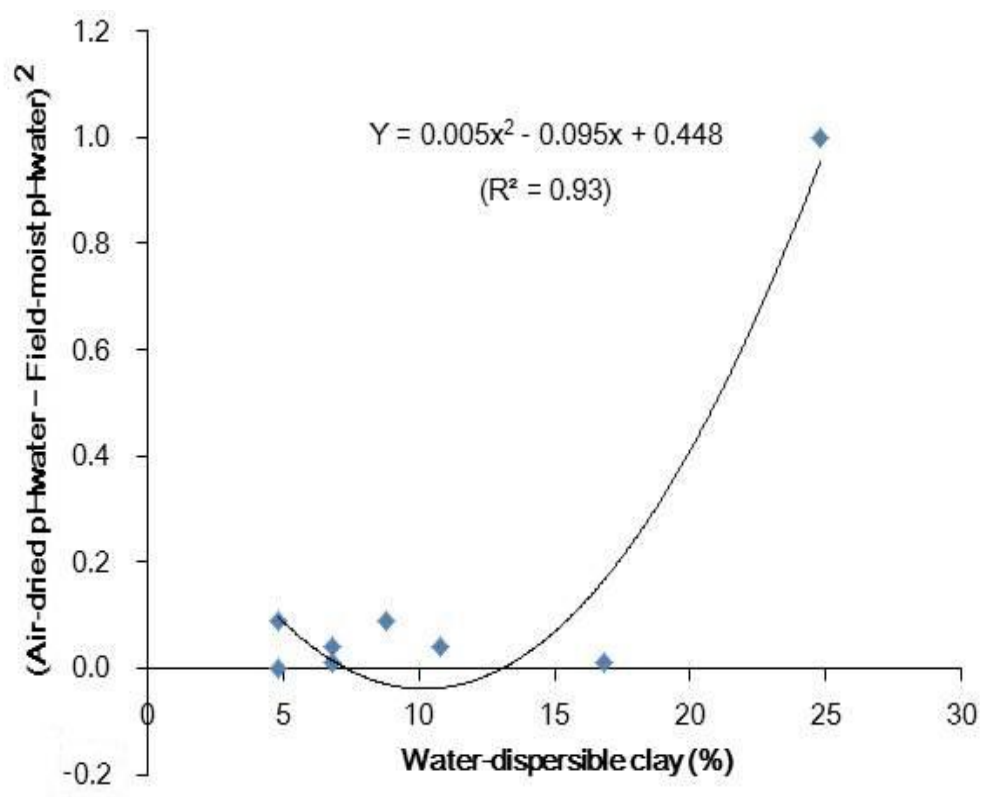

Figure 3. Quadratic linear regression of the squared differences in mean soil $\mathrm{pH}-\mathrm{H}_{2} \mathrm{O}$ of airdried and field-moist samples on water-dispersible clay (WDC) contents of the soils

One way to appreciate further the role of soil content of WDC in the effect of airdrying on soil $\mathrm{pH}$ is to examine the linear (rather than polynomial) relationship between $\mathrm{pH}$ values in air-dried soils and those in field-moist soils with and without WDC as a regressor:

$$
\begin{gathered}
\mathrm{pH}_{\text {air-dried }}=1.084(\mathrm{~ns})+0.745 \mathrm{pH}_{\text {field-moist }}(*) \\
\left(R^{2}=0.53 ; \text { s.e. }=0.32\right) \\
\mathrm{pH}_{\text {air-dried }}=1.633(\mathrm{~ns})+0.711 \mathrm{pH}_{\text {field-moist }}(*)-0.035 \mathrm{WDC}\left(^{*}\right) \\
\left(R^{2}=0.86 ;=\text { s.e. }=0.19\right)
\end{gathered}
$$

The role of soil content of WDC was such that it not only contributed significantly (*) to the regression when included as a regressor, but also resulted in an increased $R^{2}$ value and a decreased standard error (s.e.) of the estimate. This implies that field-moist soil $\mathrm{pH}$ alone could explain about $53 \%$ of the variations in $\mathrm{pH}$ of the air-dried soils, but together with WDC could explain up to $86 \%$ of such variations. Considering the rather small number of observations $(n=8)$ in these regressions, however, this relationship is not meant for use in predicting the effect of air-drying on soil $\mathrm{pH}$, but to highlight the 
underlying influence of soil colloidal stability in drying-induced differences in soil $\mathrm{pH}$. Notably, the WDC had a much stronger correlation with $\mathrm{pH}$ values of air-dried soils than with those of field-moist soils (data not shown), an indication that the observed role of WDC in explaining the drying-induced differences in $\mathrm{pH}$ was due mainly to its effect on $\mathrm{pH}$ of the air-dried soil.

In the case of available phosphorus $(\mathrm{P})$, the linear regression of values in the air-dried soils on their counterparts in the field-moist soils in itself showed a good fit:

$$
\begin{aligned}
\mathrm{P}_{\text {air-dried }}= & -0.232(\mathrm{~ns})+1.102 \mathrm{P}_{\text {field-moist }}(*) \\
& \left(R^{2}=0.91 ; \text { s.e. }=2.17\right)
\end{aligned}
$$

Similar to this relationship, Gilliam and Richter (1988), who also worked with welland poorly drained soils in South Carolina, reported that the intercept, slope and $\mathrm{R}^{2}$ values for the regression of phosphorus extractable from air-dried and ground samples on that from field-moist samples of the well-drained soil were $0.35,1.25$ and 0.90 , respectively. They, however, did not obtain any meaningful regression for the poorly drained soil of their study.

There was a corresponding further improvement in the above linear regression due to inclusion of the gradient in $\mathrm{pH}$ of the field-moist soil samples $\left(\mathrm{pH}-\mathrm{H}_{2} \mathrm{O}\right.$ minus $\mathrm{pH}-\mathrm{KCl}$, referred to as $\Delta \mathrm{pH}_{\text {field-moist }}$ ) and the clay flocculation index (CFI) in it; however, neither of these two parameters alone contributed significantly to the regression until both of them were included as regressors:

$$
\begin{gathered}
\mathrm{P}_{\text {air-dried }}=-8.911(\mathrm{~ns})+0.933 \mathrm{P}_{\text {field-moist }}(*)+10.492 \Delta \mathrm{pH}_{\text {field-moist }}(\mathrm{ns}) \\
\left(R^{2}=0.95 ;=\text { s.e. }=1.74\right) \\
\mathrm{P}_{\text {air-dried }}=-4.408(\mathrm{~ns})+1.217 \mathrm{P}_{\text {field-moist }}(*)+6.014 \mathrm{CFI}(\mathrm{ns}) \\
\left(R^{2}=0.93 ;=\text { s.e. }=2.10\right) \\
\mathrm{P}_{\text {air-dried }}=-15.684(*)+1.056 \mathrm{P}_{\text {field-moist }}(*)+12.147 \Delta \mathrm{pH}_{\text {field-moist }}(*)+7.783 \mathrm{CFI}(*) \\
\left(R^{2}=0.98 ;=\text { s.e. }=1.10\right)
\end{gathered}
$$

The increase in $R^{2}$ value and the corresponding decrease in s.e. of the estimate was also greater with both $\Delta \mathrm{pH}_{\text {field-moist }}$ and CFI as regressors than with either of them alone. These results first suggest that air-drying effect on phosphorus extractability has to do with its influence on soil $\mathrm{pH}$, and that such influence is mainly on the $\Delta \mathrm{pH}_{\text {field-moist }}$, a parameter which represents the extent by which $\mathrm{H}^{+}$is solubilized less in $\mathrm{H}_{2} \mathrm{O}$ than in $\mathrm{KCl}$ from colloids of the field-moist soil. Second, drying-induced differences in extractable phosphorus may not directly be influenced by soil colloidal stability, but whether the drying-mediated influence of soil $\mathrm{pH}$ would be evident or not depends on the soil colloidal stability. Again, these relationships are not meant for use in predicting the effect of air-drying on soil extractable phosphorus, but to highlight the underlying interplay between soil $\mathrm{pH}$ and soil colloidal stability. The correlation of CFI with available phosphorus was only slightly weaker for air-dried than for field-moist soils (data not shown). Considering that CFI was derived from data for air-dried soil samples, this similarity of the correlations appears to support the results attained for extractable phosphorus of its rather insensitivity to air-drying of soil samples before analysis. 
From the data of this study, Akaeze soil appears unique in some ways and it is apparent that this soil drives many of the patterns shown. As the only location in the derived savannah, Akaeze records longer dry season than the rest (see Table 1), a situation implying greater 'drying effect' and hence higher soil organic matter whose role in air-drying effect has already been highlighted. Again, soil organic matter relates positively with WDC, an index of clay dispersion (Igwe and Udegbunam, 2008), and Akaeze soil showed high WDC contents while showing low CFI compared to others. This not only accounts for the prominence of Akaeze in our study but also links this location to the observation here that WDC and CFI largely explained the overall results for soil $\mathrm{pH}$ and extractable phosphorus, respectively in response to air-drying.

\section{Conclusions}

The study reported here has the unique feature of assessing air-drying effect on soil $\mathrm{pH}$ and available phosphorus for both well-drained upland soils and adjoining poorly drained lowland counterparts in different locations, and relating such effects to colloidal stability of the soils. The practice of air-drying soil samples before analysis may or may not affect soil $\mathrm{pH}$, depending on location and soil drainage status at the time of sampling. Although air-drying may not always have effect, air-dried samples of welldrained, less acidic soils show increased acidity upon rewetting; whereas those of poorly drained, more acidic soils behave in the opposite. The effect of air-drying on phosphorus extractability is location-specific too and often not pronounced, but with an overall tendency of enhancing this phenomenon in well-drained soils and reducing it in poorly drained soils with relatively 'high' phosphorus status. It appears, however, that this trend is reversed in poorly drained soils having field-moist available phosphorus beyond a critical value of $15 \mathrm{mg} \mathrm{kg}^{-1}$. Overall, air-drying for $\mathrm{pH}$ and available phosphorus test is deemed safe and is thus still recommended for only well-drained upland soils with properties approximating those included in this study. Caution is needed only for soils with potentially high level $\left(>15 \mathrm{mg} \mathrm{kg}^{-1}\right)$ of available phosphorus. In such cases, the import of our data also lies in the possible impact of drying under field conditions when soil sampling programs overlap the interface between the distinct rainy and dry seasons of the tropics, even if the soils are analysed field-moist.

Soil $\mathrm{pH}$ and available phosphorus may not exhibit any meaningful relationships in these soils under natural conditions of rather narrow range of soil $\mathrm{pH}$. However, the relationships are positive and tend to be stronger for field-moist soils, on one hand and for poorly drained soils, on the other. Soil colloidal stability has an underlying influence on effects of air-drying, with WDC content and CFI influencing such effects on soil $\mathrm{pH}$ and available phosphorus, respectively. The underlying influence of WDC can be more distinct compared to that of CFI, as the latter relies on a $\mathrm{pH}$ factor to manifest. These results are expected to provoke more studies aimed at exploring fully the roles of soil colloidal stability in drying-induced differences in soil $\mathrm{pH}$ and available phosphorus as well as the mechanisms involved.

Acknowledgments. Mr Cajetan A. Iwueze, a technologist with the Department of Soil Science, University of Nigeria, Nsukka assisted the authors during soil sampling and with some aspects of the laboratory analyses. 


\section{REFERENCES}

[1] Achat D.L., Augusto L., Gallet-Budynek A., Bakker M.R. (2012): Drying-induced changes in phosphorus status of soils with contrasting soil organic matter contentsimplications for laboratory approaches. - Geoderma 187-188: 41-48.

[2] Bartlett R., James B. (1980): Studying dried, stored soil samples - some pitfalls. - Soil Science Society of America Journal 44: 721-724.

[3] de Oliveira T.S., de Costa L.M., Schaefer C.E. (2005): Water-dispersible clay after wetting and drying cycles in four Brazilian Oxisols. - Soil \& Tillage Research 83: 260-269.

[4] Dowding C.E., Borda M.J., Fey M.V., Sparks D.L. (2005): A new method for gaining insight into the chemistry of drying mineral surfaces using ATR-FTIR. - Journal of Colloid and Interface Science 292: 148-151.

[5] Ekpete D.M. (1976): Evaluation of chemical methods for the determination of available phosphorus in waterlogged soils. - Soil Science 121: 217-221.

[6] Enwezor W.O., Moore A.W. (1966): Phosphorus status of some Nigerian soils. - Soil Science 102 (5): 322-328.

[7] Enwezor W.O. (1977): Soil testing for phosphorus in some Nigerian soils: I. comparison of methods of determining available phosphorus in soils of southeastern Nigeria. - Soil Science 123 (1): 48-53.

[8] Erich M.S., Hoskins B.R. (2011): Effects of soil drying on soil pH and nutrient extractability - Communications in Soil Science and Plant Analysis 42: 1167-1176.

[9] Eze O.C., Loganathan P. (1990): Effects of $\mathrm{pH}$ on phosphate sorption of some paleudults of southern Nigeria. - Soil Science 150: 613-621.

[10] Gee G.W., Bauder J.W. (1986): Particle size analysis. (In A. Klute (Ed.), Methods of Soil Analysis, Part 1: Physical and Mineralogical Properties. Agronomy Monograph no. 9 (pp. 91-100). Madison Wisconsin: American Society of Agronomy.)

[11] Gilliam F.S., Richter D.D. (1988): Correlations between extractable Na, K, Mg, Ca, P \& $\mathrm{N}$ from fresh and dried samples of two Aquults. - Journal of Soil Science 39: 209-214.

[12] Haynes R.J., Swift R.S. (1985). Effects of air-drying on the adsorption and desorption of phosphate and levels of extractable phosphate in a group of acid soils, New Zealand. Geoderma 35: 145-157.

[13] Igwe C.A., Obalum S.E. (2013): Microaggregate stability of tropical soils and its roles on soil erosion hazard prediction, Advances in Agrophysical Research (Chapter 8), Stanisław G. (ed.), ISBN: 978-953-51-1184-9, InTech, DOI: 10.5772/52473

[14] Igwe C.A., Udegbunam O.N. (2008): Soil properties influencing water-dispersible clay and silt in an Ultisol in southern Nigeria. - International Agrophysics 22: 319-325.

[15] Kaiser M., Kleber M., Berhe A.A. (2015): How air-drying and rewetting modify soil organic matter characteristics: An assessment to improve data interpretation and inference. - Soil Biology and Biochemistry 80: 324-240.

[16] Loganathan P., Isirimah N.O., Nwachuku D.A. (1987): Phosphorus sorption by Ultisols and Inceptisols of the Niger Delta in southern Nigeria. - Soil Science 144: 330-338.

[17] Mbagwu J.S.C., Schwertmann U. (2006): Some factors affecting clay dispersion and aggregate stability in selected soils of Nigeria. - International Agrophysics 20: 23-30.

[18] McLean E.O. (1982): Soil pH and lime requirement. (In A.L. Page (Ed.), Methods of Soil Analysis, Part 2: Chemical Methods. Agronomy Monograph no. 9 (pp. 199-224). Madison Wisconsin: American Society of Agronomy.)

[19] Marx E.S., Hart J., Stevens R.G. (1999): Soil Test Interpretation Guide, Oregon State University, Oregon.

[20] Mokwunye U. (1975): The influence of $\mathrm{pH}$ on the adsorption of phosphate by soils from the guinea and sudan savannah zones of Nigeria. - Soil Science Society of America Journal 39: 1100-1102. 
[21] Obalum S.E., Buri M.M., Nwite J.C., Hermansah, Watanabe Y., Igwe C.A., Wakatsuki T. (2012a): Soil degradation-induced decline in productivity of sub-Saharan African soils: the prospects of looking downwards the lowlands with the sawah ecotechnology. Applied and Environmental Soil Science, Vol. 2012: Article ID 673926, 10 pages, doi:10.1155/2012/673926

[22] Obalum S.E., Nwite J.C., Watanabe Y., Igwe C.A., Wakatsuki T. (2012b): Comparative topsoil characterization of sawah rice fields in selected inland valleys around Bida, northcentral Nigeria: physicochemical properties and fertility status. - Tropical Agriculture and Development 56: 39-48.

[23] Obalum S.E., Watanabe Y., Igwe C.A., Obi M.E., Wakatsuki T. (2014): Improving on the prediction of cation exchange capacity for highly weathered and structurally contrasting tropical soils from their fine-earth fractions. - Communications in Soil Science and Plant Analysis 44: 1831-1848.

[24] Obalum S.E., Watanabe Y., Igwe C.A., Obi M.E., Wakatsuki T. (2014): Puddling intensity for late-season sawah systems based on soil hydrophysical conditions and rice performance. - International Agrophysics 28: 331-340.

[25] Olsen S.R., Sommers L.E. (1982): Phosphorus. (In A.L. Page, R.H. Miller and D.R. Keeny (Eds.), Methods of Soil Analysis, Part 2: Chemical Properties (2nd Ed.). Agronomy Monograph no. 9 (pp. 15-72). Madison Wisconsin: American Society of Agronomy.)

[26] Owusu-Bennoah E., Ampofo J.G., Acquaye D.K. (1995): Phosphorus status of some semi-arid agricultural soils of northern Ghana. - Ghana Journal of Agricultural Science 28-29: 29-35.

[27] Owusu-Bennoah E., Awadzi T.W., Boateng E., Krogh L., Breuning-Madsen H., Borggaard O.K. (2000). Soil properties of a toposequence in the moist semi-deciduous forest zone of Ghana. - West African Journal of Applied Ecology 1: 1-10.

[28] Peltovuori T., Soinne H. (2005): Phosphorus solubility and sorption in frozen, air-dried and field-moist soil. - European Journal of Soil Science 56: 821-826.

[29] Rabeharisoa L., Razanakoto O.R., Razafimanantsoa M.-P., Rakotoson T., Amery F., Smolders E. (2012): Larger bioavailability of soil phosphorus for irrigated rice compared with rainfed rice in Madagascar: results from a soil and plant survey. - Soil Use and Management 28: 448-456.

[30] Sato S., Comerford N.B. (2005): Influence of soil pH on inorganic phosphorus sorption and desorption in a humid Brazilian Ultisol. - Revista Brasileira de Ciência do Solo 29: 685-694.

[31] Schaerer M., Frossard E., Sinaj E. (2005): Effects of air drying on soil available phosphorus in two grassland soils. - Geophysical Research Abstracts, European Geophysical Society 5: 10315.

[32] Soinne H., Räty M., Hartikainen H. (2010): Effect of air-drying on phosphorus fractions in clay soil. - Journal of Plant Nutrition and Soil Science 173: 332-336.

[33] Srivastava S.C. (1997): Microbial contribution to extractable N and P after air-drying of dry tropical soils. - Biology and Fertility of Soils 26 (1): 31-34.

[34] Thomas G.W. (1996): Soil pH and soil acidity. (In D.L. Sparks, A.L. Page, P.A. Helmke et al., (Eds.), Methods of Soil Analysis, Part 3: Chemical Methods. Soil Science Society of America Book Series No. 5 (pp. 475-490). Madison WI.)

[35] Xiao W.-J., Song C.-L., Cao X.-Y., Zhou Y.-Y. (2012). Effects of air-drying on phosphorus sorption in shallow lake sediment, China. - Fresenius Environmental Bulletin 21: 672-678.

[36] Xu G., Sun J.N., Xu R.F., Lv Y.C., Shao H.B., Yan K., Zhang L.H., Blackwell M.S.A. (2011). Effects of air-drying and freezing on phosphorus fractions in soils with different organic matter contents. - Plant, Soil and Environment 57: 228-234.

[37] Yongsong Z., Xianyong L., Wuzhong N. (1998): Effects of flooding and subsequent airdrying on phosphorus adsorption, desorption and available phosphorus in the paddy soils. - Chinese Journal of Rice Science 12: 40-44. 